\title{
Analysis of Market Participation Behavior Among Smallholder Dairy Farmers in Uganda
}

\author{
Elizabeth K. Balirwa ${ }^{1} \&$ Emmanuel Waholi ${ }^{1}$ \\ ${ }^{1}$ Department of Agribusiness and Natural Resource Economics, Makerere University, Kampala, Uganda \\ Correspondence: Elizabeth K. Balirwa, Department of Agribusiness and Natural Resource Economics, Makerere \\ University, P.O. Box 34224, Kampala, Uganda. Tel: 256-782-431-247. E-mail: elizabethkb@caes.mak.ac.ug; \\ elizabethkuteesa@gmail.com
}

Received: August 12, 2018

Accepted: December 9, 2018 Online Published: February 15, 2019

doi:10.5539/jas.v11n3p109

URL: https://doi.org/10.5539/jas.v11n3p109

\begin{abstract}
Market participation of smallholder farming has gained priority in the policy agenda of many developing countries as an engine for economic growth. In Uganda, smallholder dairy farming has been adopted as a strategy for the country's economic transformation through commercialization but efforts to improve dairy market sales have not been successful. Without appropriate interventions, Uganda may fail to take advantage of the anticipated increase in demand for livestock products. A study to analyze determinants of dairy farmers' market participation and percentage of milk sales was therefore undertaken in Uganda's three main milk producing regions. Multistage sampling and purposive sampling procedures were used to select a study sample of 171 representative dairy farming households, with at least one milking cow based on data derived from the REPEAT Survey of 2012. Data was analyzed by descriptive statistics and Heckman two-stage selection econometric model. Results show that milk market entry decision was significantly influenced by improved lactating cows $(1 \%)$, number of lactating cows $(1 \%)$, milk yield $(1 \%)$, information access $(5 \%)$, access to veterinary services $(5 \%)$ and children less than 6 years $(10 \%)$. Percentage of milk sales was influenced by information access (1\%), number of lactating cows (5\%), improved milking breeds $(5 \%)$ and quantity of milk consumed. Three variables critical to policy intervention in enhancing smallholder dairy farmer participation and intensification are number of lactating cows, improved lactating cows and information access. Quantity of milk consumed suggests supplementation of milk with other protein foods among dairy farmers in Uganda.
\end{abstract}

Keywords: smallholder, milk, market participation, 2 stage-heckman model

\section{Introduction}

Market participation of smallholder farming has gained priority in the developing world as an engine for economic growth. This prioritization of smallholder farming has been reflected in the policy agenda of many developing countries (Demeke \& Haji, 2014). This could be a result of the anticipated increase in demand for livestock products as Ehui et al. (2002) projected total consumption of meat and milk in Sub-Saharan Africa (SSA) to more than double, from 11.3 to 35.4 million tons between 1997 and 2020. Moreover, Delgado et al. (1999) had earlier projected a 50\% increase in per capita consumption of livestock products from 1993 to 2020. Such increases are attributed to population growth, urbanization and rising incomes in developing countries, which cause an outward shift in the demand for livestock especially dairy products. As Heltberg and Tarp (2001) observed, this rising demand presents expanding market opportunities among rural people in SSA (in particular, increased milk sales, market information, market entry, entrepreneurships and incomes). Accordingly, increased participation in markets by smallholder farming households is an important strategy for better incomes and possibly poverty escape and spells food security in developing countries (Heltberg \& Tarp, 2001). Besides, increasing market participation was earlier underscored by Delgado (1998) as a key factor to lifting households out of poverty in African countries.

Developing country governments are directing effort to improve market access, expecting significant return in meeting Sustainable Development Goals (SDGs) of poverty reduction and zero hunger anticipated by 2030 (MFPED, 2016). Interventions aimed to increase market participation and product sales in Sub Saharan African countries are therefore major strategies that need to be addressed to take advantage of the projected increase in demand for agricultural products, especially livestock. For agro-based economies such as Uganda ( $80 \%$ agrarian), 
market development is crucial for the increasing population and urbanization. However, many households face a major constraint of inability to participate in markets, which makes it impossible to combat poverty. Despite Uganda government efforts to transform the agriculture sector, many farmers remain largely in subsistence farming with little level of commercialization. Lack of smallholder dairy market participation has been reported a major constraint to poverty reduction in Uganda (UBOS, 2016). Efforts to improve livestock products market sales are therefore paramount to the Ugandan economy as they lead to increases in productivity and sale (supply) of agricultural (livestock) products. Without the stated interventions, Uganda may fail to take advantage of the anticipated increase in demand for livestock products.

There is almost exhaustive literature on market participation in decades before 2010 including that by Woldemichael (2008), Bellemare and Barrett (2006), Staal and Ehui (2004), Ahmed et al. (2004), Ehui (2003), Muriuki and Thorpe (2001), Delgado (1998), Goetz (1992), Key et al. (2000), Holloway et al. (2005), Yigezu (2000), Muriuki and Thorpe (2001), Redda (2002), and Sadoulet and De Janvry (2000). These studies do not address dairy technology (type of breed) as an independent variable influencing market participation. However, technology (type of dairy breed) is a major influencing factor to participation decision and sales. Studies on relationships between dairy technology and participation are almost non exixtent. There are few studies in the decade after 2010, including; Chamboko et al. (2017) in Zimbabwe; Benyam et.al. (2016), and Berhanu et al. (2014) in Ethiopia, which have applied Heckman econometric models to address market participation objectives, these studies focus on volume and not on proportion or percentage sales, which affects intensity of participation somewhat differently. This study on milk market participation and technology relationships addresses the stated information gaps in order to contribute to the development policy interventions aimed to enhance smallholder farmers' milk market participation and improvement in the percentage of milk sales.

\section{Methodology}

\subsection{Description of the Study Area}

Uganda lies between latitude $4^{\circ} 12^{\prime} \mathrm{N}$ and $1^{\circ} 29^{\prime} \mathrm{S}$; longitude $29^{\circ} 34^{\prime} \mathrm{E}$ and $35^{\circ} 0^{\prime} \mathrm{N}$. It has a total land area of 241,551 square kilometers with a population of approximately 42.8 million (PRB, 2017). The average daily temperature ranges from $15-31{ }^{\circ} \mathrm{C}$ and an average annual rainfall range from $735-1863 \mathrm{~mm} /$ year. This type of climate allows generally good rains in most parts of the country that permit plenty of forage and water for livestock, which enables relatively high milk yield for much of the year. Seasonality in milk supply however, still occurs. The country's climate permits production of mixed breeds including locals and the high yielding breeds (crosses and exotics). The study was carried out in Uganda's three main milk producing regions (Southwestern, Central and Eastern).

\subsection{Sampling Techniques}

The study uses a secondary data set of Research on Poverty, Environment and Agricultural Technologies (REPEAT) household level survey project of National Graduate Institute for Policy Studies (GRIPS) and Makerere Uiversity for the year 2012. The survey aimed to identify agricultural technologies and farming systems with potential to contribute to increased agricultural productivity and reduced poverty in Uganda. The survey involved 91 communities (LC1s, which is the country's lowest administrative unit). Multistage sampling and purposive sampling procedures were used to select representative households for analysis. The dataset consisted of 916 households from which 282 households were purposively selected on the criterion that they had at least one milking cow per household, at the time of the survey (2012). The study further purposively selected five districts from each of the 3 milk producing regions (Southwestern, Central and Eastern) having the highest number of milk producing households out of six milk shades (regions). Households with missing information on variables of interest for this study were dropped to remain with a complete data set of 171 households for study. They included $61 \mathrm{~h} / \mathrm{h}$ from eastern region, $55 \mathrm{~h} / \mathrm{h}$ from south western and $51 \mathrm{~h} / \mathrm{h}$ from central region.

\subsection{Methods of Data Analysis}

Data was analyzed using the Statistical Package for Social Sciences (SPSS) and STATA (Version 14) software. Two types of data analysis, namely descriptive and econometric (quantitative) statistics were used to analyze the data. Descriptive methods of data analysis included percentages, means, t-tests and chi-square tests. These statistics first examined and compared smallholder characteristics of milk market participants and non-market participants of selected dairy households. Econometric analysis applied the Heckman two-step selection model to examine the determinants of milk market participation and percentage of milk sales. 


\subsubsection{Theoretical Framework of the Heckman Model}

An econometric model known as Heckman two-step estimation procedure was developed by Heckman (1979) to specifically correct for sample selectivity bias, in cases that would involve two decisions such as participation and intensity or degree of participation. In the case of the present study the decision to participate in milk markets can be seen as a sequential two-stage decision making process. Households make a discrete choice on whether to participate in milk markets or not, in the first stage. In the second stage, these households make continuous decisions on how much sell or what percentage or proportion of milk should be sold, based on the first decision to sell milk. This means that the first stage of the Heckman two-stage model is a 'participation equation', which attempts to capture factors that affect one's decision to participate in a given activity. This equation is then used to construct a selectivity term or variable known as the 'inverse Mills ratio'. This variable is then added to the second stage equation that explains factors affecting percentage or proportion of milk sales. The inverse Mill's ratio is a variable for controlling bias due to sample selection (Heckman, 1979). This therefore makes the Heckman (1979) two- step estimation procedures most appropriate for the study at hand.

After adding the Mills ratio to the milk sales equation, the equation is then estimated using Ordinary Least Square (OLS). For the participation equation to be confirmed, the coefficient of the 'selectivity' term has to be significant, meaning, the hypothesis that an unobserved selection process governs the participation equation. Moreover, including the said extra term, the coefficient in the second stage 'selectivity corrected' equation is unbiased (Zaman, 2001).

\subsubsection{Model Specification}

The two-stage Heckman procedure is written in terms of the probability of milk market participation, and marketed milk Percentage. To apply this model to the present study, the researcher tracked literature on empirical studies of selectivity models (Goetz, 1992; Key \& Delgado, 1998; Holloway et al., 1999; Sadoulet \& De Janvry, 2000; Nicholso, Heltberg, \& Tarp, 2001; Staal \& Ehui, 2004; Bellemare \& Barrett, 2006).

Following procedure by selectivity models, determinants of smallholder dairy farmer decision to participate in milk markets and intensity or percentage of milk sales in Uganda, was considered as a sequential two-stage decision process. Firstly, households make a discrete choice on whether to participate or not (whether to deliver milk or not to milk collection centers). Secondly and conditional on farmer decision to participate, they make continuous decisions on what proportion or percentage of milk should be sold to collection centers.

In the first-stage, the standard probit model is used, following the random utility model as specified by Wooldridge (2002):

$$
\begin{gathered}
\mathrm{Y}^{*}=\mathrm{x}^{\prime} \beta+\varepsilon_{1} \\
\mathrm{Y}=1 \text { if } \mathrm{Y}^{*}>0 \\
\mathrm{Y}=0 \text { if } \mathrm{Y}^{*} \leq 0
\end{gathered}
$$

Where,

$\mathrm{Y}^{*}=$ is a latent (unobservable) variable representing farmer's discrete decision whether to sell milk or not; $\mathrm{x}^{\prime}=$ is a vector of independent variables hypothesized to affect farmer's decision to participate in the milk market; $\beta$ $=$ is a vector of parameters to be estimated which measures the effects of explanatory variables on the farmer's decision; $\varepsilon_{1}=$ is normally distributed disturbance with mean $(0)$ and standard deviation of $(\delta, 1)$. It captures all unmeasured variables; $\mathrm{Y}=$ is a dependent variable which takes on the value of 1 , if the farmers participated in the milk markets and 0 otherwise.

The probit parameter estimates do not show by how much a particular variable increases or decreases the likelihood of farmer market participation. For this reason, this study considered and reported the marginal effects of the independent variables on the probability of a smallholder dairy farming household to participate in milk markets. The variables determining level of participation are estimated using the second-stage Heckman selection model (Heckman, 1979). The Heckman selection equation is specified as:

$$
\begin{gathered}
\mathrm{Z}_{\mathrm{i}}^{*}=\mathrm{Wi} \alpha+\varepsilon_{2} \\
\mathrm{Z}_{\mathrm{i}}=\mathrm{Zi}^{*} \text { if } \mathrm{Zi}^{*}>0 \\
\mathrm{Z}_{\mathrm{i}}=0 \text { if } \mathrm{Zi}^{*} \leq 0
\end{gathered}
$$

Where,

$Z_{i}^{*}=$ latent variable representing the desired or optimal level of participation which is observed if $Z_{i}^{*}>0$ and unobserved otherwise; $Z_{i}=$ is the observed level of participation; $W_{i}=$ vector of covariates for unit $i$ for selection 
equation which is a subset of $Z^{\prime} ; \alpha=$ vector of coefficients for selection equation; $\varepsilon_{2}=$ random disturbance for unit i for selection equation.

\subsubsection{Correction for Selection Bias in the Second Stage}

The two equations ( 1 and 2) in the two-stage decision process are not separable due to unmeasured farmer variables determining both the discrete and continuous decision thereby leading to the correlation between the errors of the equations. There are unobservable variables in the first stage, which influence occurrence of the second stage, causing correlation in the error terms of the two equations (1 and 2). If the two errors are correlated, the estimated parameter values on the variables determining the level of participation are biased (Wooldridge, 2002). Thus, we need to specify a model that corrects for selectivity bias while estimating the determinants of the level of participation. The analysis therefore needs to create in the first-step, a Mills ratio using predicted probability values obtained from the first-stage probit regression of the participation decision. The Mill's ratio is hence included in the second stage as one of the independent variables postulated to influence the level (percentage) of farmer participation to form a regression equation Thus, the level of participation equation with correction for sample selection bias becomes:

$$
\mathrm{V} \%=\mathrm{W}_{\mathrm{i}} \alpha+\lambda\left[\frac{\phi\left(\mathrm{W}_{\mathrm{i}} \alpha\right)}{\Phi\left(\mathrm{W}_{\mathrm{i}} \alpha\right)}\right]+\varepsilon_{3}
$$

Where,

$\phi(.) / \Phi($.$) is the Mills ratio; \lambda$ is coefficient on the mills ratio; $\phi$ is the standard normal probability density function; $\Phi$ is the standard cumulative distribution function; $\varepsilon_{3}=$ is not correlated with $\varepsilon_{1}, \varepsilon_{2}$ and other independent variables. Under the null hypothesis; no sample selection bias; $\lambda$ is not significantly different from zero; $\mathrm{V} \%=$ is the level of participation (Percentage of milk sold per day).

Table 1. Description of the variables in the empirical models

\begin{tabular}{|c|c|c|c|c|c|}
\hline \multirow[b]{2}{*}{ Variable name } & \multirow[b]{2}{*}{ Description } & \multirow[b]{2}{*}{$\begin{array}{l}\text { Variable } \\
\text { type }\end{array}$} & \multirow[b]{2}{*}{ Variable measurement } & \multicolumn{2}{|c|}{ Expected Sign } \\
\hline & & & & $\begin{array}{l}\text { First } \\
\text { stage }\end{array}$ & $\begin{array}{l}\text { Second } \\
\text { stage }\end{array}$ \\
\hline \multicolumn{6}{|l|}{ Dependent variables } \\
\hline Market participation & Milk market participation decision & Dummy & $\begin{array}{l}1 \text { if household participated in the milk market, } 0 \\
\text { otherwise }\end{array}$ & N.A & N.A \\
\hline Percentages sales & Percentage of milk sale & Continuous & $\begin{array}{l}\text { Percentage of milk supplied to the market out of the } \\
\text { total household production }\end{array}$ & N.A & N.A \\
\hline \multicolumn{6}{|l|}{ Explanatory variables } \\
\hline Sex & Sex of household head & Dummy & 1 if household head is male, 0 otherwise & + & + \\
\hline Age & Age of household head & Continuous & Number of years & $+/-$ & $+/-$ \\
\hline Education level & Educational level of head of household & Continuous & Number of years in school & $+/-$ & + \\
\hline Household size & Number of people in a household & Continuous & Number of people & + & $+/-$ \\
\hline Children less 6 years & $\begin{array}{l}\text { Number of children in the household less than } \\
6 \text { years of age }\end{array}$ & Continuous & Number of children & $+/-$ & - \\
\hline Milk consumed & Average quantity of milk consumed & Continuous & Litres consumed by household per day & $+/-$ & $+/-$ \\
\hline Land size & Total size of land holding of the household & Continuous & acres & $+/-$ & + \\
\hline Milk yield & Milk yield per household & Continuous & litres per household per cow per day & + & + \\
\hline No. of lactating cows & Number of dairy lactating cows & Continuous & Number of lactating cows & + & + \\
\hline $\begin{array}{l}\text { Only Improved lactating } \\
\text { cows }\end{array}$ & Ownership of improved lactating cows & Dummy & $\begin{array}{l}1 \text { if household owned only improved lactating cows, } \\
0 \text { otherwise }\end{array}$ & + & + \\
\hline Both local and improved & Ownership of both local and improved breeds & Dummy & $\begin{array}{l}1 \text { if household owned both local and improved } \\
\text { lactating cows, } 0 \text { otherwise }\end{array}$ & + & + \\
\hline Access to information & Access to dairy information & Dummy & 1 if household information, 0 otherwise & + & + \\
\hline Bicycle & Ownership of a bicycle & Dummy & 1 if household owned a bicycle, 0 otherwise & + & + \\
\hline Motorcycle & Ownership of a motorcycle & Dummy & 1 if household owned a motorcycle, 0 otherwise & + & + \\
\hline Vet services & Access to veterinary services & Dummy & $\begin{array}{l}1 \text { if household accessed veterinary services, } 0 \\
\text { otherwise }\end{array}$ & + & + \\
\hline Credit access & $\begin{array}{l}\text { Access to credit for dairy production } \\
\text { improvement }\end{array}$ & Dummy & 1 if household accessed credit services, 0 otherwise & + & + \\
\hline Nonfarm employment & $\begin{array}{l}\text { Household head earning income from other } \\
\text { sources }\end{array}$ & Dummy & 1 if household had non-farm income, 0 otherwise & $+/-$ & $+/-$ \\
\hline
\end{tabular}

Note. Source: Author's definitions, 2018. 


\subsection{Model Evaluation and Testing for Regression Diagnostics}

Regression diagnostics involve a number of tests that is checking the data for; normality, multicollinearity and heteroscedasicity before the model can be run for analysis

\subsubsection{Testing for Normality and Log Transformations of Variables}

To ensure getting unbiased estimates, continuous variables were tested for normality graphically using a histogram. Gujarati (1995) states that log transformation of numerical variables helps to eliminate skewness and kurtosis. All variables in the study that did not conform to normality assumption were transformed to fit a normal distribution (Appendix A).

\subsubsection{Testing for Multicollinearity}

Before running the Heckman two stage models, the exogenous variables were checked for existence of multicollinearity problems. A multicollinearity situation occurs when the explanatory variables display little variation and/or high inter-correlation (Maddala, 1992). This implies that if there exists an association between continuous independent variables, then a problem of multicollinearity is likely to occur. The test is done in order to conform to the regression requirement that the errors must be homogenous. Multicollinearity is measured by a value /statistic referred to as the Variance Inflation Factor (VIF). According to Green (1997), the threshold value of the VIF is 10 and that a highly positive value of the VIF indicates that there is significant Multicollinearity in the model. All variables included in the analysis gave values of the VIF less than 10 and tolerance values (1/VIF) greater than 0.1, therefore warranting further investigation. The higher the value of VIF (Xi) the more difficult or collinear the variable $\mathrm{Xi}$ is. As a rule, if the VIF of an explanatory variable is greater than 10 , then a multicollinearity problem exists. Accordingly, the VIF (Xi) results in 2012 data set showed that the data had no serious problem of multicollinearity. This is because, for all the 17 (seventeen) exogenous variables, the values of VIF were less than 10. Therefore, all the exogenous variables were rightly included in the model (Appendix B).

\subsubsection{Testing for Heteroscedasticity}

Heteroscedasticity among explanatory variables was tested using Breusch-pagan/Cook-Weisbergin test. The null hypothesis for the test is that there is no heteroscedasticity among the variables (i.e. the variance among variables across the sample is constant or Homoskedasticity). If the heteroscedasticity test P-value is not significant, it implies that there is no problem of heteroscedasticity. If the p-value is significant it implies that there is a problem of heteroscedasticity among variables in the sample (i.e. variance among variables across the sample are not constant but vary). In this situation robust standard errors of the Huber/White/sandwich estimators of variance can be used to correct for possible heteroscedasticity of unknown form (White, 1980; Vella, 1998) such that the regression requirement that the errors must be homogenous is fullfilled. However, the heteroscedasticity test $\mathrm{P}$-value was found not to be significant (i.e. $\mathrm{P}=0.3004)$, implying that there was no problem of heteroscedasticity (Appendix C).

\section{Results and Discussion}

\subsection{Socio-economic and Demographic Characteristics of Milk Market Participants and Non-Participants}

Descriptive statistics (mean and t-test) for continuous household variables indicated that market participants and non-market participants had statistical significant differences at $1 \%$ level among four variables including milk yield in liters per cow per day, number of improved lactating cows, level of education and number of lactating cows per household. Variables with significant difference at 5\% level, between participants and non-participants are; size of land size, quantity of milk consumed in litres per household per day and size of herd per household. The key features of the variables used in the study are shown in the Table 2. 
Table 2. Mean Socio-economic characteristics of milk market participants and non-participants, 2012 production year

\begin{tabular}{|c|c|c|c|c|}
\hline Variable & $\begin{array}{l}\text { Market participants } \\
(\mathrm{n}=\mathbf{8 0})\end{array}$ & $\begin{array}{l}\text { Non-participants } \\
(\mathrm{n}=91)\end{array}$ & t-statistic & p-values \\
\hline Age (number of years) & 52.1 & 53.8 & 0.705 & 0.4818 \\
\hline Education (years in school) & 7.0 & 5.5 & -2.616 & $0.0097 * * *$ \\
\hline Household size (No. of people in a $\mathrm{H} / \mathrm{H}$ ) & 13.3 & 12.5 & -0.923 & 0.3573 \\
\hline No. of children under 6 years of age & 1.5 & 1.3 & 0.766 & 0.4448 \\
\hline Land size (acres) & 16 & 8.8 & -2.185 & $0.0303 * *$ \\
\hline Quantity of milk consumed litres per $\mathrm{H} / \mathrm{H}$ per day & 0.5 & 0.3 & -2.372 & $0.0188^{* *}$ \\
\hline Milk yield in liters per cow/day & 4.5 & 2.2 & -4.811 & $0.0000 * * *$ \\
\hline No. of local lactating cows per $\mathrm{H} / \mathrm{H}$ & 1.7 & 1.5 & -0.437 & 0.6629 \\
\hline No. of improved lactating cows per $\mathrm{H} / \mathrm{H}$ & 1.5 & 0.3 & -5.406 & $0.0000 * * *$ \\
\hline No. of lactating cows per $\mathrm{H} / \mathrm{H}$ & 3.1 & 1.8 & -3.003 & $0.0031 * * *$ \\
\hline Herd size per $\mathrm{H} / \mathrm{H}$ & 12.2 & 6 & -2.424 & $0.0164 * *$ \\
\hline
\end{tabular}

Note. $*, * *$ and $* * *$ significant at $10 \%, 5 \%$ and $1 \%$ respectively.

The average number of years spent in school by household heads was higher for market participants ( 7 years) compared to non-participants (5.5 years) and significantly different at $1 \%$ level. This implies that education had positive influence in the milk market participation (Benyam Tadesse et al., 2016). This outcome emphasizes the importance of education in enhancing participation decision as it attracts technology acceptance and uptake, which support market participation. Marenya and Barret (2007) found a strong and positive significant association between the education variable and market participation among smallholder farmers in western Kenya. Education increases skill and successful implementation of improved production, processing and marketing practices, which all increase product output and market participation. Significant mean difference in number of years spent in school between market participants and non-participants is reported among smallholder dairy value chain actors in Zimbabwe (Chamboko, 2017) and Benyam et al. (2016) and Berhanu et al. (2014) in Ethiopia.

Size of land in acreage owned by a household was higher for market participants (16 acres) than non-participants (8.8 acres) and registered significant difference between participants and non-participants at 5\% level. This could have influenced the size of herd (12.2 heads) which participants had over non-participating households with half the number (6 heads of cattle).

Quantity of milk consumed by households per day was higher for participants ( 0.5 litres per day) than non-participants ( 0.3 liters per day) and significantly different at $5 \%$ between the two groups. This emphasizes the nutritional effect that households with more milk output (higher yields) consumed more quantities of milk than those with reduced milk yields.

The average milk yield for market participating (4.5 liters per cow) and non-participating (2.2 liters per cow) households was significant at $1 \%$ level. Those with higher yields are likely to participate in milk markets implying that milk yield is positively associated with market participation. Depending on the number of lactating cows a household has, a higher yield facilitates higher milk output and marketable surplus. The association could also be that income from sale of milk enables participating households to access yet more yield increasing resources from the market, which further increases production of milk.

The average number of local lactating cows for market participants (1.7 cows) and non-participants (1.5cows) were not significantly different. However, ownership of improved lactating cows associated with milk market participation. Milk participants had more improved lactating cows (1.5) compared to non-participants $(0.3)$ and the difference in average number of lactating cows between the two categories was statistically significant at $1 \%$.

Size of herd was positively associated with participation in that milk participants had more than twice (12.2 heads) than heads of cows owned (6 heads) by non-participants and significantly different at $5 \%$ level. Participation yields income which can be re-invested to acquire more assets especially livestock.

These results suggest that milk market participation is directly associated (influenced) by milk yield, number of improved lactating cows, number of lactating cows per household, education of dairy farmer, size of herd per household, quantity of milk consumed by a household per day and size of grazing land a farmer has. 
Variables that were not statistically different between the participating and non-participating households were age of household head, household size, number of children less than 6 years of age and number of local lactating cows owned. The average age was 52.1 years for participants and 53.8 years for non-participants, while size of household was averagely 13 for market participants and 12.5 for non-participants. Each category had less than 2 children below 6 years.

The Chi-square test results for categorical variables (Table 3) show that type of milking breeds owned, access to information and access to veterinary services were statistically significant (1\%) between market participants and non-market participants. Results show an association between type of breed and participation in that among participants, majority ( $45 \%$ ) had improved breeds, followed by those with only local breeds who were $38.75 \%$, whereas majority of households that did not participate in the milk market kept only local breeds $(79.12 \%)$. The implication of these results is that households that keep improved breeds are more likely to participate in milk marketing than those keeping local or both types of breeds (mixed breed category). Participating households with access to veterinary services were $31.25 \%$ while only $14.29 \%$ of non-participating households did not access veterinary services. Those who access veterinary services are more likely to receive technical knowledge for improved productive performance leading to higher yields and hence surplus milk which precipitates participation decision and market sales.

Information access was associated with participation at $1 \%$ level. Approximately $94 \%$ participants accessed information while non-participants who accessed information were $79.12 \%$. This implies that household with access to information were more likely to participate in the milk market than those without access. Dairy farmers who access information are able to make better marketing arrangements for their products and even reduce on transaction costs in milk marketing.

Table 3. Proportion of socio economic characteristics of participants and non-participants

\begin{tabular}{|c|c|c|c|c|}
\hline Variable & $\begin{array}{l}\text { Market participants } \\
(n=80)\end{array}$ & $\begin{array}{l}\text { Non participants } \\
(\mathrm{n}=91)\end{array}$ & Chi-square value & p-values \\
\hline \multicolumn{5}{|l|}{ Sex } \\
\hline Male & 91.25 & 93.41 & 0.2819 & 0.595 \\
\hline Female & 8.75 & 6.59 & & \\
\hline Marital status (Married) & 90.00 & 87.91 & 0.1879 & 0.665 \\
\hline \multicolumn{5}{|l|}{ Transport assets } \\
\hline Bicycle (Yes) & 71.25 & 65.93 & 0.5568 & 0.456 \\
\hline Motorcycle (Yes) & 25.00 & 10.99 & 5.7773 & $0.016^{* *}$ \\
\hline Moto vehicle (Yes) & 7.50 & 1.10 & 4.4432 & $0.035 * *$ \\
\hline \multicolumn{5}{|l|}{ Milking breeds } \\
\hline Only local & 38.75 & 79.12 & & \\
\hline Only improved & 45.00 & 16.48 & 29.1452 & $0.000 * * *$ \\
\hline Both local and improved & 16.25 & 4.40 & & \\
\hline \multicolumn{5}{|l|}{ Institutional factors } \\
\hline Access to information (Yes) & 93.75 & 79.12 & 7.5515 & $0.006^{* * *}$ \\
\hline Veterinary services (Yes) & 31.25 & 14.29 & 7.0886 & $0.008 * * *$ \\
\hline Non- farm income (Yes) & 48.75 & 32.97 & 4.4061 & $0.036^{* *}$ \\
\hline Credit (Yes) & 77.50 & 74.73 & 0.1798 & 0.672 \\
\hline
\end{tabular}

Note. ${ }^{*},{ }^{* *}$ and ${ }^{* * *}$ significant at $10 \%, 5 \%$ and $1 \%$ respectively.

Ownership of a motor vehicle and non-farm income were significantly associated with milk market participation at $5 \%$ level. Percentage of households with a motor vehicle was higher for market participants $(7.5 \%)$ campared to non-participants (1.1\%). This shows that a motor vehicle is an important transport asset among households as it facilitates access to various markets and distribution of greater milk sales despite the fact that motor vehicles were owned by very few households (less than $10 \%)$. Majority of the households owned bicycles $(71.25 \%$ for participants and $65.93 \%$ for non-participants). This shows the importance of bicycles in smallholder dairy farming although the chi-square test shows that bicycle ownership has no significant relationship with market participation. 
Other variables with Chi-square values showing no significant difference between participants and non-participants in milk marketing were sex of the household head, marital status and access to credit. Male headed households however, dominate smallholder dairy farming i.e. 91.25\% among participants and $93.41 \%$ among non-participants. Marital status had no significant relationship with milk market participation, although majority of respondents (participants and non-participants) were married.

Table 4. Milk market participation behavior of dairy farming households

\begin{tabular}{ll}
\hline Characteristics & 2012(n = 171) \\
\hline Milk market Participation & \\
Yes & $46.78 \%$ \\
No & $53.22 \%$ \\
Daily production per household & 8.2 litres \\
Daily milk yield per household & 3.26 litres \\
Volume sold by households per day & 4.2 litres \\
Proportion of milk sold per day & 0.61 \\
\% milk sold per day per household (level of participation) & $61 \%$ \\
\hline
\end{tabular}

Out of 171 households, $46.78 \%$ of the smallholder dairy producers in 2012 data were classified as market participants and the remaining households (53.22\%) did not participate in selling milk. Daily milk yield was 3.26 litres per cow. Daily milk production was 8.2 litres per day on average, market participants sold 4.2 litres of milk per day with percentage participation of $61 \%$ of the daily milk production. These results imply that smallholder dairy producers in Uganda still need support to increase their involvement in milk marketing and increase milk market sales for dairy sector development.

\subsection{Factors Affecting Milk Market Participation by Household Derived From $1^{\text {st }}$ Stage (Probit) Heckman Model}

The analysis first tested for model fitness or reliability and appropriateness whereby the first stage probit model was estimated by maximum likelihood method using data obtained. The Log-likelihood Ratio (LR) for this model was highly significant at the $1 \%$ level (Prob $>$ chi $2=0.0000)$ (Table 5). This is an indication that all the explanatory variables included in the model jointly influenced households' likelihood to participate in selling milk. A pseudo $\mathrm{R}^{2}$ of 0.30 shows that the model has a good fit to the data (Table 5). Based on the above measures for model reliability and appropriateness (i.e. goodness of model fitness), we conclude that the probit model employed was reliable and appropriate.

Results show six (6) variables that significantly explained the likelihood of milk market participation by households in Uganda's major milk producing regions (Southwestern, Central and Eastern). The most important variables include a household having only improved lactating cows (1\%), number of lactating cows owned by a household $(1 \%)$, milk yield in liters per cow per day $(1 \%)$, information access $(5 \%)$, access to veterinary services/animal health (5\%) and a family having children less than 6 years $(10 \%)$.

As hypothesized, household having only improved lactating cows had a significantly higher likelihood to participate in the milk market compared to households with only local lactating cows at $1 \%$ level. Households with mixed milking breeds (local and improved breeds) also had a significantly higher likelihood to participate in the milk market compared to households with pure local lactating cows at $10 \%$ level. According to Benyam et. al. (2016) and Woldemichael, (2008), improved dairy breeds facilitate market entry decision of a household because they are high yielding compared to local breeds leading to availability of milk marketable surplus. Thus availing improved cows alongside local cows is an important policy relevant variable in stimulating the smallholder to market entry.

Contrary to prior expectations number of children less than 6 years in a household had a positive and significant effect on the households' likelihood to participate in the milk market at $10 \%$ level. An increase in number of children in a household is likely to increase household expenditure hence children are a driving factor for a household to participate in the milk market. Berhanu et al. (2014) hypothesized number of children less than six years of age in a household to negatively influence market participation with an argument that there is competition between milk for child requirement and amount needed for market; however the variable was not found significant contrary to findings of this study. 
Table 5. Marginal effects for determinants of probability of milk market participation

\begin{tabular}{|c|c|c|c|}
\hline Variables & Coef. (Std. Err.) & dy/dx (Std. Err.) & $\mathbf{P}>\mathbf{z}$ \\
\hline Sex of household head & $-0.3342(0.4647)$ & $-0.1314(0.1774)$ & 0.459 \\
\hline Age of household head & $0.0019(0.010)$ & $0.0007(0.0040)$ & 0.853 \\
\hline Education level & $0.0115(0.0328)$ & $0.0045(0.0131)$ & 0.727 \\
\hline Household size & $-0.2723(0.3129)$ & $-0.1086(0.1248)$ & 0.384 \\
\hline Children less 6 years & $0.4687(0.2902)$ & $0.1841(0.1107)$ & $0.096^{*}$ \\
\hline Milk consumed & $0.0121(0.0950)$ & $0.0048(0.0387)$ & 0.901 \\
\hline Total Land size & $-0.1074(0.1371)$ & $-0.0429(0.0547)$ & 0.433 \\
\hline Milk yield & $0.1812(0.0683)$ & $0.0723(0.0272)$ & $0.008 * * *$ \\
\hline No. of lactating cows & $0.1955(0.0710)$ & $0.07798(0.0283)$ & $0.006^{* * *}$ \\
\hline Only Improved lactating cows & $0.8611(0.2948$ & $0.3261(0.1006)$ & $0.001 * * *$ \\
\hline Both local and improved & $0.8022(0.5020)$ & $0.2955(0.1568)$ & $0.060^{*}$ \\
\hline Access to information & $0.8282(0.3932)$ & $0.3080(0.1260)$ & $0.014 * *$ \\
\hline bicycle & $0.1394(0.2547)$ & $0.0556(0.1013)$ & 0.583 \\
\hline Motor cycle & $0.2156(0.3540)$ & $0.0856(0.1394)$ & 0.539 \\
\hline Veterinary services & $0.5642(0.3129)$ & $0.2195(0.1158)$ & $0.058^{*}$ \\
\hline Credit access & $0.1704(0.2732)$ & $0.0678(0.1083)$ & 0.531 \\
\hline Nonfarm employment & $0.1871(0.2549)$ & $0.0745(0.1012)$ & 0.462 \\
\hline Constant & $-1.8773(1.0081)$ & & \\
\hline \multicolumn{4}{|l|}{ Number of obs $=171$} \\
\hline \multicolumn{4}{|l|}{ LR $\operatorname{chi} 2(17)=71.80$} \\
\hline \multicolumn{4}{|l|}{ Prob $>$ chi $2=0.0000$} \\
\hline \multicolumn{4}{|l|}{ Log likelihood $=-82.275563$} \\
\hline Pseudo R2 $=0.3038$ & & & \\
\hline
\end{tabular}

Note. $*, * *$ and $* * *$ significant at $10 \%, 5 \%$ and $1 \%$ respectively.

Daily milk yield had a positive and significant effect on the household's decision to participate in the milk market at $1 \%$ level of significance. An increase in milk yield significantly increased the likelihood of that household to participate in the milk market as hypothesized. According to Berhanu et al. (2014) and Bardhan et al. (2012), a marginal increase in milk yield has an obvious and significant effect in motivating market participation.

Number of lactating cows had a positive and significant effect on a household's decision to participate in the milk market at $1 \%$ level, as prior hypothesized. The model output predicts that adding one more milking cow to a household significantly increases the likelihood of that household to participate in the milk market. As number of lactating cows increases, milk production per household increases which in turn increases percentage share of milk sales per household per day (Berhanu et al., 2014; Benyam et al., 2016; Chamboko et al., 2017).

Household access to information positively and significantly influenced the likelihood of a household to participate in the milk market as expected at 5\% significance level. Farmers marketing decisions are based on market price information. Access to information leads to understanding of the workings of the market, information on prices, and other market information improves farmer decision to participate (Chamboko et al., 2017). Goetz (1992) showed that better market information significantly raised probability of market.

Access to veterinary services significantly influenced the decision of a household to participate in the milk market at $10 \%$ level of significance positively as hypothesized. It is expected that dairy farming households which have access to veterinary services have health sound dairy animals and also widen the household's knowledge with regard to the use of improved dairy production technologies and this is likely to influence milk market participation decision of a household positively. According to Quddus (2013), and Dehinenet (2014) knowledge on improved technologies through training, availability of reliable and continuous technical assistance, increased and timely provision of medicine, increasing A.I facilities and strengthening extension services increased use of improved technologies among dairy households.

Contrary to earlier expectations, sex of the household head, age, household size, education, household size, average quantity of milk consumed per household per day, ownership of a bicycle, access to credit and possession of non-farm employment had no significant influence on the household's decision to participate in the milk market at $1 \%, 5 \%$ and $10 \%$ levels of significance. 


\subsection{Factors Affecting Milk Market Participation by Household Derived From $1^{\text {st }}$ Stage (Probit) Heckman Model}

Determinants of percentage of milk sales by smallholder dairy farmers were estimated using the second stage Heckman selection model (Table 6). The overall joint goodness of fit for second stage Heckman selection model parameter estimates was assessed based on Wald chi square test. The null hypothesis for the test is that all coefficients are jointly zero. The test indicates that the overall good fit for the model is statistically significant at $1 \%$ level of significance. This shows that jointly independent variables included in the selection model significantly explained the percentage of milk sales by the studied households.

The second stage Heckman model revealed five (5) significant explanatory variables influencing the percentages of milk sales out of 16 variables. The significant explanatory variables are; quantity of milk consumed per day by household (10\%), Number of lactating cows (5\%), improved lactating cows $(5 \%)$, access to information (1\%) and lamda (5\%).

As hypothesized, number of milking had a positive and significant effect on the percentage of milk sales by a household at 5\% level. This result suggests that marketable percentage of milk of the household in the study areas are more responsive to number of lactating cows kept by farming household. Studies by Holloway and Ehui, (2002) reported that milk production varies directly with the number of lactating dairy cows, as number of dairy cows increases, milk production also increases and percentage share of consumption declines and milk sales increases. Similarly Benyam et al. (2016), and Chamboko et al. (2017) reported a positive relationship between number of lactating cows and level of milk market participation in terms of volume of milk sold. Bardhan et al. (2012) study in India report that the milk output sold depends on resource ownership like land and animal holding and farmer specific variables.

Quantity of milk consumed per household per day had a negative effect on the percentage of milk sales by a household per day at $10 \%$ level. An increase in milk consumption by household significantly reduces marketable surplus and likely to negatively affect percentage sold. Many farmers in Sub-Saharan Africa remain at the subsistence level, with production activities mainly conducted for home consumption (Verheye, 2000). This leaves megre percentage sales hence the negative relationship as hypothesized.

Table 6. Heckman second stage results for percentage of milk sales by household per day

\begin{tabular}{|c|c|c|c|c|}
\hline Variables & Coef. & Std. Err. & $\mathbf{z}$ & $\mathbf{P}>\mathbf{Z}$ \\
\hline Sex & -2.9683 & 11.5766 & -0.26 & 0.798 \\
\hline Age & -0.0226 & 0.2530 & -0.09 & 0.929 \\
\hline Education & 1.1198 & 0.8503 & 1.32 & 0.188 \\
\hline Household size & 1.0384 & 8.5665 & 0.12 & 0.904 \\
\hline Children less 6 years & -2.2186 & 8.3972 & -0.26 & 0.792 \\
\hline Qty of milk consumed & -3.6831 & 2.6030 & -1.91 & $0.057^{*}$ \\
\hline Total land size owned & -3.2744 & 3.5054 & -0.93 & 0.350 \\
\hline Milk yield & 1.0126 & 0.9732 & 1.04 & 0.298 \\
\hline No. of lactating cows & 2.8750 & 1.1356 & 2.53 & $0.011 * *$ \\
\hline Improved lactating cows & 21.5422 & 8.9809 & 2.40 & $0.016^{* *}$ \\
\hline Both local and improved cows & 10.7621 & 11.2838 & 0.95 & 0.340 \\
\hline Access to information & 29.0842 & 10.4173 & 2.79 & $0.005 * * *$ \\
\hline Bicycle & 7.7592 & 7.2270 & 1.07 & 0.283 \\
\hline Motorcycle & 7.9457 & 8.8683 & 0.90 & 0.370 \\
\hline Veterinary services & -6.1328 & 7.7646 & -0.79 & 0.430 \\
\hline Lambda & 23.6122 & 11.3302 & 2.08 & $0.037 * *$ \\
\hline \multicolumn{5}{|l|}{ Number of obs $=171$} \\
\hline \multicolumn{5}{|l|}{ Censored obs $=91$} \\
\hline \multicolumn{5}{|l|}{ Uncensored obs $=80$} \\
\hline \multicolumn{5}{|l|}{ Wald chi2 $(15)=186.12$} \\
\hline \multicolumn{5}{|l|}{ Prob $>$ chi $2=0.0000$} \\
\hline \multicolumn{5}{|l|}{ Rho $=0.82908$} \\
\hline Sigma $=0.28480156$ & & & & \\
\hline
\end{tabular}


Access to information by household positively influenced the percentage of milk sold by household, at $1 \%$ level. Information access enables a famer to reach out to distant markets and locate milk demand areas. It also facilitates linkage with many milk buyers hence higher percentage sales. Goetz (1992) similarly reported a positive relationship between access to information by a household and level of market participation. However several studies: Chamboko et al. (2017); Berhanu et al. (2014); Benyam et al. (2016); and Holloway and Ehui (2002) hypothesized that market information is positively related to marketable surplus (Volume of milk sold) though not found significant.

Ownership of improved milking breeds significantly influenced the percentage of milk sales positively at $5 \%$ level. Households with improved breeds sold a higher percentage of milk per day compared to households with only local lactating cows. Improved dairy breeds are high yielding compared to local breeds leading to availability of milk marketable surplus (Woldemichael, 2008). Promotion of improved dairy cows significantly increases the intensity of milk market participation among smallholder dairy farmers.

Lambda coefficient of Mills ratio was positive and significant at 5\% level, implying significant correlation of error terms in the 1st and 2nd stage of the heckman selection model. This signifies sample selection bias, existence of some unobservable farmer characteristics affecting likelihood to participate in the milk market and thus affecting percentage of milk sold. The correction for selectivity bias is significant justifying the use of stage 2 heckman selection model for analysis to estimate determinants of the milk participation decision and percentages of milk sales by a dairy household.

\section{Recommendations and Conclusion}

Smallholder dairy farmer drivers to milk participation include; ownership of improved lactating cows, number of lactating cows, milk yield, information access and access to veterinary services. Children tend to drive up family expenditures and this compels households to commercialize the dairy farming enterprise. Important variables to percentage of milk sales are information access, number of lactating cows and ownership of improved lactating cows but quantity of milk consumed negatively affects milk sales.

The study recommends important policy intervention instruments to enhance both smallholder milk market participation and percentage milk sales in Uganda. The study recommends; improvement of dairy technology in particular upgrading dairy breeds, empowering dairy farmers in accessing and use of more appropriate information and communication technologies. The study also recommends increasing numbers of lactating cows per household per year and improving on lactating intervals among smallholder dairy farming households. A review and extension of support to the existing dairy improvement program is recommended to specifically target the various dairy production systems and provide continuous training, veterinary services/animal health services and market access facilities (transport facilities, information etc.). Smallholder dairy producers are not fully commercialized and need increased support to intensify their involvement in milk marketing and milk sales for dairy sector development.

\section{Acknowledgements}

I acknowledge the support by principal academic advisor (Professor Dick, Sserunkuuma).

\section{References}

Ahmed, M. M., Ehui, S., \& Assefa, Y. (2004). Milk development in Ethiopia. EPTD Discussion Paper No. 123. Washington, DC, USA.

Alene, A. D., Manyong, V. M., Omanya, G., Mignouna, H. D., Bokanga, M., \& Odhiambo, G. (2008). Smallholder Market Participation under Transactions Costs: Maize Supply and Fertilizer Demand in Kenya. Food Policy, 33(4), 318-328. https://doi.org/10.1016/j.foodpol.2007.12.001

Balirwa, E. K., Nalunkuuma, J., \& Sserunkuuma, D. (2016). Determinants of smallholder dairy farmers' volume of milk sales in Uganda's agro-ecological zones. International Journal of Applied and Pure Science and Agriculture, 2(8), 97-109. Retrieved from http:/ijapsa.com/published-papers/volume-2/issue-8/determinan ts-of-smallholder-dairy-farmers-volume-of-milk-sales-in-ugandas-agro-ecological-zones.pdf

Bardhan, D., Sharma, M. L., \& Saxena, R. (2012). Market participation behaviour of smallholder farmers in Uttarakhand: A disaggregated analysis. Agricultural Economics Review, 25(2), 243-254. Retrieved from http://ageconsearch.umn.edu/record/137367/files/6-D-Bardhan.pdf

Bellemare, M. F., \& Barrett, C. B. (2006). An ordered Tobit model of market participation: Evidence from Kenya and Ethiopia. American Journal of Agricultural Economics, 88(2), 324-337. https://doi.org/10.1111/ j.1467-8276.2006.00861.x 
Benyam T., Zekarias S., \& Taye T. (2016). Determinants of Dairy Farmers' Market Participation in the Major Dairy Producing Towns of Jimma Zone of Southwest Ethiopia. Food Science and Quality Management Journal, 52.

Berhanu, K., Derek, B., Kindie, G., \& Belay, K. (2014). Factors Affecting Milk Market Participation and Volume of Supply in Ethiopia. Asian Journal of Rural Development, 4, 1-15. https://doi.org/10.3923/ajrd.2014.1.15

Chamboko, T., Mwakiwa, E., \& Mugabe, P. H. (2017). Determinants of Milk Market Participation and Volume of Sales to Milk Collection Centres of the Smallholder Dairy Value Chain in Zimbabwe. Journal of Agricultural Science, 9(10), 156. https://doi.org/10.5539/jas.v9n10p156

Dehinenet, G., Mekonnen, H., Kidoido, M., Ashenafi1, M., \& Guerne Bleich, E., (2014). Factors influencing adoption of dairy technology on small holder dairy farmers in selected zones of Amhara and Oromia National Regional States, Ethiopia. Discourse Journal of Agriculture and Food Sciences, 2(5), 126-135.

Delgado, C. (1998). Africa's Changing Agricultural Development Strategies: Past and Present Paradigms as a Guide to the Future. The Brown Journal of World Affairs, 5(1), 175-214.

Demeke, L., \& Haji, J. (2014). Econometric analysis of factors affecting market participation of smallholder farming in Central Ethiopia (MPRA Paper 77024). University Library of Munich, Germany.

Ehui, S., Benin, S., \& Paulos, Z. (2003). Policy options for improving market participation and sales of smallholder livestock producers: A case study of Ethiopia. International Conference on African Development Archives, 77.

Gizachew, G. (2005). Dairy Marketing Patterns and Efficiency: The Case of Ada'Liben District, eastern Oromia (Unpublished M. Sc. Thesis, Haramaya University, Ethiopia).

Goetz, S. J. (1992). A selectivity model of household food marketing behaviour in Sub-Saharan Africa. American Journal of Agricultural Economics, 74(2), 444-452. https://doi.org/10.2307/1242498

Gujarati, D. N. (1995). Basic Econometrics (3rd ed.). McGraw-Hill International Editions, New York

Heltberg, R., Simler, K., \& Tarp, F. (2001). Public spending and poverty in Mozambique (No. 2001/63). World Institute for Development Economics (UNU-WIDER).

Heckman, J. J. (1979). Sample selection bias as a specification error. Econometrica, 47, 153-161. https://doi.org/ $10.2307 / 1912352$

Holloway, G. J., \& Ehui, S. (2002). Expanding market participation among smallholder livestock producers: $A$ collection of studies employing Gibbs sampling and data from the Ethiopian highlands, 1998-2001 (Vol. 48). ILRI (ILCA and ILRAD).

Holloway, G., Barrett, C. B., \& Ehui, S. (2005). The double-hurdle model in the presence of fixed costs. J. Int. Agric. Trade Dev., 1, 17-28.

Holloway, G., Nicholson, C., Delgado, C., Staal, S., \& Ehui, S. (2004). A revised Tobit procedure of mitigating bias in the presence of non-zero censoring with an application to milk-market participation in the Ethiopian highlands. Agricultural Economics, 31, 97-106. https://doi.org/10.1111/j.1574-0862.2004.tb00224.X

Jabbar, M. A., Ehui, S. K., \& Von Kaufmann, R. (2002). Supply and demand for livestock credit in sub-Saharan Africa: Lessons for designing new credit schemes. World Development, 30(6), 1029-1042. https://doi.org/ 10.1016/S0305-750X(02)00021-9

Key, N., Sadoulet, E., \& De Janvry, A. (2000). Transactions Costs and Agricultural Household Supply Response. American Journal of Agricultural Economics, 82, 245-259. https://doi.org/10.1111/0002-9092.00022

Lefebo, H., Haji, J., Geta, E., \& Zemedu, L. (2016). Determinants of Status and Extent of Market Participation among Bulla Producers in Hadiya Zone. Southern Ethiopia Journal of Biology, Agriculture and Healthcare $6(7)$.

MFPED (Ministry of Finance, Planning and Economic Development). (2016). Background to the Budget, Financial Year 2017/2018. Industrialization for Job Creation and Shared Prosperity.

Maddala, G. S. (1992). Introduction to Econometrics (2nd ed.). Newyork: Macmillan Publishing Campany.

Mbitsemunda, J., \& Karangwa, A. (2017). Analysis of Factors Influencing Market Participation of Smallholder Bean Farmers in Nyanza District of Southern Province, Rwanda. Journal of Agricultural Science, 9(11). https://doi.org/10.5539/jas.v9n11p99 
Muriuki, H. G., \& Thorpe, W. (2001). Smallholder dairy production and marketing in Eastern and Southern Africa. Proceedings of the South-South Workshop on Smallholder Dairy Production and Marketing-Constraints and Opportunities, March 12-16, 2001, Annand, India.

PRB (Population Reference Bureau). (2017). World population data sheet.

Quddus, M. A. (2012). Adoption of dairy farming technologies by small farm holders: Practices and constraints. Bangladesh Journal of Animal Science, 41(2), 124-135.

Redda, T. (2002). Small-scale milk marketing and processing in Ethiopia. Smallholder dairy production and market opportunity and constraints. Proceeding of a South-South workshop held at NDDB, March 13-16, 2001, Anand, India (pp. 352-367).

Rehima, M., (2006). Pepper marketing chains analysis: The case of Alaba and Siraro districts, Southern Ethiopia (M.Sc. Thesis, Haramay University, Ethiopia).

Staal, S. J., Baltenweck, I., Njoroge, L., Patil, B. R., Ibrahim, M. N. M., \& Kariuki, E. (2006). Smallholder dairy farmer access to alternative milk market channels in Gujarat. Proceedings of the 26th Conference of the International Association of Agricultural Economists, August 12-18, 2006, Brisbane, Australia (pp. 1-15).

Tanga, F. K., Jabbar, M. A., \& Shapario, B. I. (2000). Gender roles and child nutrition in livestock production systems in developing countries: A critical review. Socioeconomics and Policy Research Paper No. 27 (pp. 1-64). ILRI, Nairobi, Kenya.

Uganda Bureau of Statistics. (2016). The national population and housing census 2014-Main report.

Vella, F. (1998). Estimating models with sample selection bias: A survey. Journal of Human Resources, 127-169. https://doi.org/10.2307/146317

Verhye, W. H. (2000). Local farmers would be able to feed Africa if they were given the chance. Nature, 404(6777), 431-431. https://doi.org/10.1038/35006732

White, H. (1980). A heteroskedasticity-consistent covariance matrix estimator and a direct test for heteroskedasticity. Econometrica: Journal of the Econometric Society, 817-838. https://doi.org/10.2307/ 1912934

Woldemichael, S. (2008). Dairy marketing chains analysis: the case of shashemane, Hawassa and dale district's milk shed, southern Ethiopia (Thesis Submitted to the Department of Agricultural Economics, School of Graduate Studies, Haramaya University).

Wooldridge, J. M. (2002). Econometric Analysis of Cross Section and Panel Data (p. 752). MIT Press, Cambridge, MA.

Yaynabeba, A., \& Tewodros, T. (2013). Factors influencing market participation decision and extent of participation of haricot bean farmers in Meskan District, Ethiopia. International Journal of Management and Development Studies, 2(8).

Yigezu, Z., (2000). Dairy development enterprise experience in milk collection: Processing and marketing. Proceedings of the Role of Village Dairy Cooperatives in Dairy Development, Smallholder Dairy Development (SDD'00), Ministry of Agriculture, Addis Ababa, Ethiopia. 


\section{Appendix A}

\section{Testing for normality}

(1) Land Size

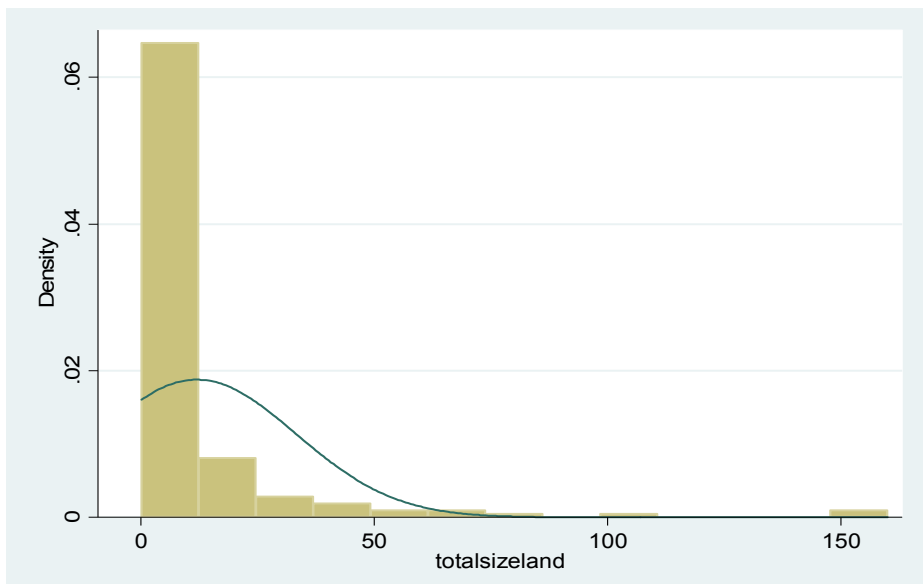

(2) Transformed Log Land Size

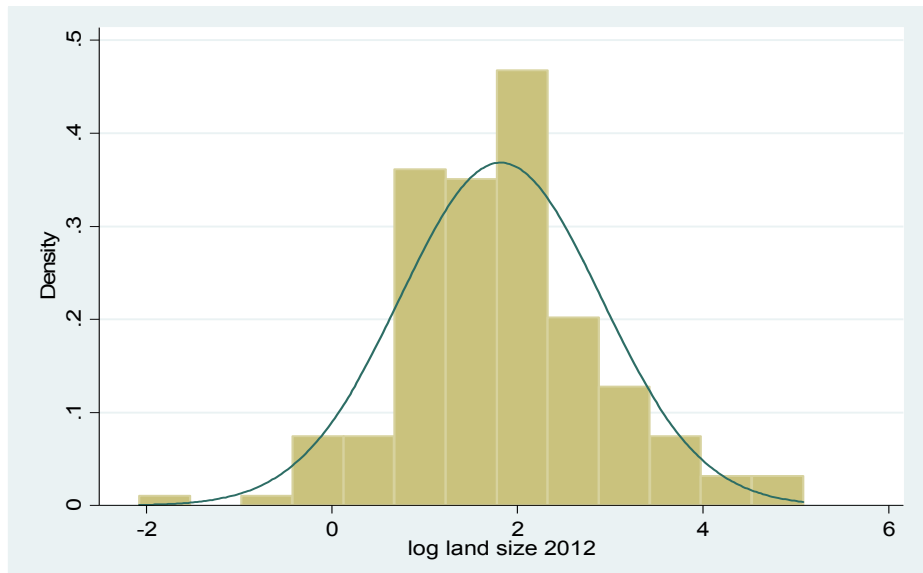

(3) Household Size

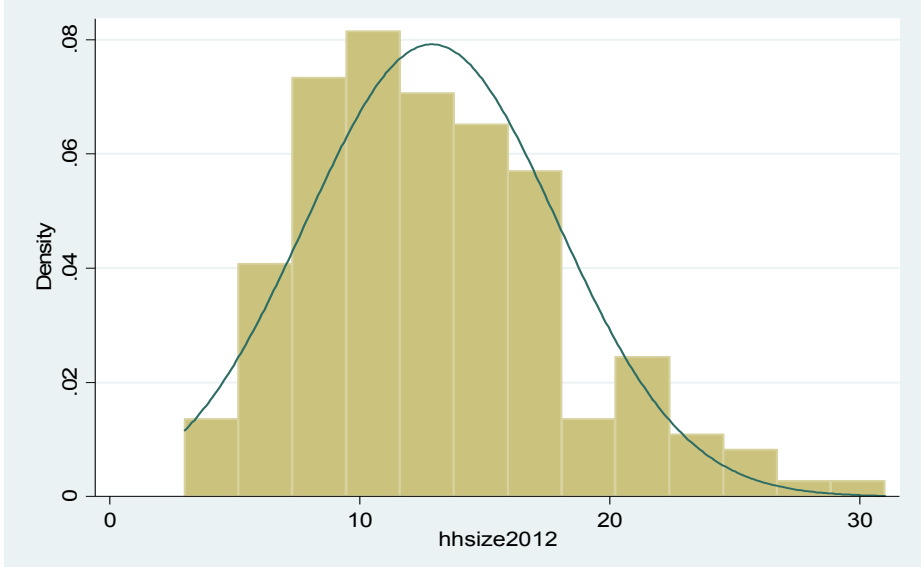


(4) Transformed Log Household Size

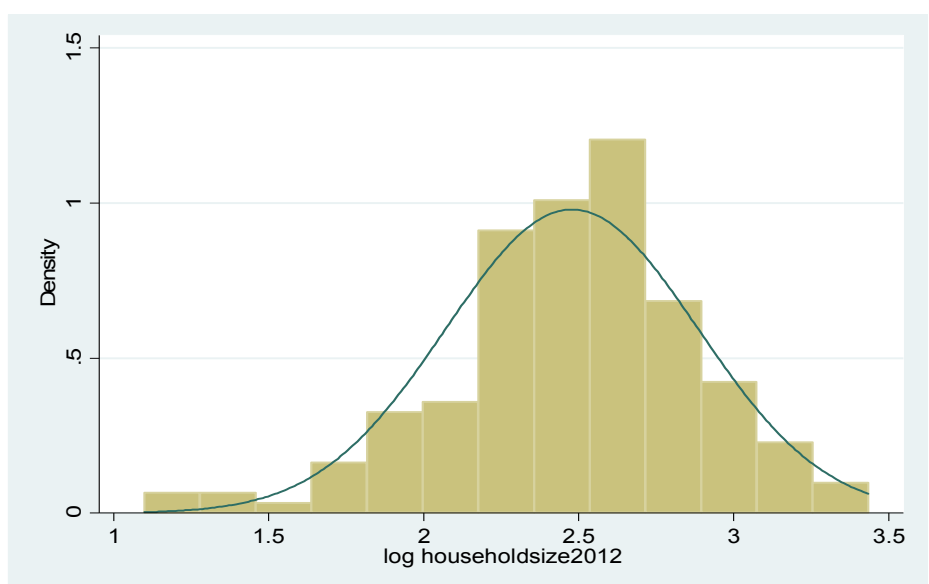

\section{Appendix B}

Variance Inflation Factor-STATA 14 results

\begin{tabular}{lll}
\hline Variable & VIF & $\mathbf{1 / V I F}$ \\
\hline loglandsize & 1.79 & 0.557961 \\
No. milk cows & 1.44 & 0.696173 \\
Age & 1.40 & 0.713882 \\
motocycle & 1.38 & 0.724908 \\
loghhsize & 1.31 & 0.761149 \\
onlyimprov y & 1.31 & 0.764821 \\
qtymilkcon & 1.30 & 0.769054 \\
milkyield12 & 1.29 & 0.776559 \\
veterinary & 1.25 & 0.798067 \\
local\&impro & 1.24 & 0.806466 \\
education & 1.23 & 0.814750 \\
nonfarminc $\sim \mathrm{e}$ & 1.23 & 0.814982 \\
childless612 & 1.23 & 0.815589 \\
sex2012 & 1.17 & 0.853571 \\
information & 1.14 & 0.876699 \\
credit & 1.11 & 0.898580 \\
bicycle & 1.11 & 0.898999 \\
Mean VIF & & $\mathbf{1 . 2 9}$ \\
\hline
\end{tabular}

\section{Appendix C}

\section{Heteroskedasticity test}

Breusch-Pagan/Cook-Weisberg test for heteroskedasticity-STATA 14 results

Ho: Constant variance

Variables: fitted values of percentage of milk sales

$\operatorname{chi} 2(1)=1.07$

Prob $>$ chi $2=0.3004$

\section{Copyrights}

Copyright for this article is retained by the author(s), with first publication rights granted to the journal.

This is an open-access article distributed under the terms and conditions of the Creative Commons Attribution license (http://creativecommons.org/licenses/by/4.0/). 